\title{
MALE PERSPECTIVE ON WOMEN IN CONTEMPORARY INDONESIAN ISLAMIC LITERATURE
}

\author{
WAJIRAN * \\ Universitas Abmad Dablan
}

\section{Abstract}

This paper aims at discussing the image of women in contemporary Indonesian Islamic literature after the 'Indonesian Reformation' in 1998. In contrast to the previous era, the images of women in this period are presented differently by male writers. Women are depicted more moderate and progressive. This paper applies the method of sociology of literature whereby literature is regarded as a reflection of its society. It employs content analysis of the text to see how Javanese Muslim women are depicted and how the depiction reflects the society. Two novels discussed in this paper are Cinta Suci Zahrana by Habiburrahman El Shirazy and Perempuan Badai by Mustofa W. Hasyim. The results show that these novels raise various issues of Muslim women in contemporary Indonesia. They show that there is a development in presenting the image of Muslim women in Indonesia. There is a development of thoughts, especially about the social status of women. The changes include the level of education, determination of spouse and freedom to participate in public spheres. The level of education obtained by the main characters is an essential milestone in changing women's position in Indonesian Muslim society. Women are not just an object, but they should be the subject in the life of the Muslim community.

\footnotetext{
* Corresponding author: Jl. Ringroad Selatan Tamanan, Bantul, Yogyakarta. Email: wajiran@enlitera.uad.ac.id.
} 


\section{WAJIRAN}

Artikel ini bertujuan membahas citra perempuan dalam literatur Islam Indonesia kontemporer setelab 'Reformasi Indonesia' pada tahun 1998. Berbeda dengan era sebelumnya, citra perempuan pada periode ini disajikan secara berbeda oleh penulis laki-laki. Wanita digambarkan lebih moderat dan progresif. Penelitian ini menerapkan metode sosiologi sastra di mana sastra dianggap sebagai cerminan masyarakatnya. Penelitian ini menggunakan analisis isi teks untuk melihat bagaimana wanita Muslim Jawa digambarkan dan bagaimana penggambaran itu mencerminkan masyarakat. Dua novel yang dibahas dalam penelitian ini adalah Cinta Suci Zabrana oleh Habiburrabman El Shirazy dan Perempuan Badai oleh Mustofa W. Hasyim. Hasil penelitian ini menunjukkan babwa novel-novel ini mengangkat berbagai masalah perempuan Muslim di Indonesia kontemporer. Dua novel ini menunjukkan bahwa ada perkembangan dalam menghadirkan citra perempuan Muslim di Indonesia. Ada perkembangan pemikiran, terutama tentang status sosial perempuan. Perubahan itu meliputi tingkat pendidikan, penentuan pasangan dan kebebasan untuk berpartisipasi dalam ruang publik. Tingkat pendidikan yang diperoleh oleh karakter utama adalah tonggak penting dalam mengubah posisi perempuan dalam masyarakat Muslim Indonesia. Perempuan bukan hanya obyek, tetapi mereka harus menjadi subjek dalam kehidupan komunitas Muslim.

Keywords: contemporary Indonesian literature; gender bias; Islamic literature; male perspective.

\section{Introduction}

This paper examines the images of women in contemporary Indonesian literature, especially that dealing with the image of women based on male perspectives. This paper focuses on the image of women in Islamic literature (sastra Islami). Islamic literature is associated with Islamic moral values, which many critics assumed that this literature discriminates against women in Muslim society. 
The existence of Islamic literature is influenced by Islamic ideology, which spread from the Arabic countries (Middle East). Therefore, in defining the meaning of Islamic literature, it cannot be separated from its original state (Nasrullah 2013). The term of Islamic literature in Arabic is al-'Adab al-Islāmī, while literature can be understood as the imitation of life. Therefore, the simple definition of Islamic literature is literature or the imitation of life that is based on the Islamic worldview.

Al-'Adab consists of moral values that cannot be separated from its authors. That is why, in the Middle East, al-'Adab is associated with the 'adī $b$, the writer. The writer of Islamic literature is regarded as a 'distinctive' person (who knows well about both life and the Islamic religion). On the other hand, al-'Adab is sometimes also associated with 'Abādìth, Prophet Muhammad's explanations about issues based on Islamic values. Osman $(2008,2)$ explains that during the Prophet Muhammad's era, the $A d a b$ is always dealt with using Islamic cognition, which is directed toward the education for individual and development of moral values (Osman 2008).

Islamic literature has received very little critical attention during its long history. Jakob Sumardjo refers to the heritage of Islamic literary works from the Soekarno era (1950 to 1965), which also include translated stories from the Middle East, initially written in Arabic. However, some were of Indian and Persian origin (Danerek 2006, 130). This neglected Islamic literature may be due to unfavorable political and social conditions, since both Soekarno and Suharto regimes strictly controlled the mass media, including literature. Soekarno instituted firm control over the press (Rosidi 1995), while in the Suharto era, every publication was required to get permission from the government authority. Any literature that promoted a particular belief or faith was forbidden. 
After the era of 1998 'Reformasi', the term of Islamic literature became popular, due to the political openness that made it possible to spread new thoughts, including the Islamic worldview (Aveling 2007; Danerek 2006; Rani 2012) As a result, Islamic literature in the 'Reformasi' is regarded as the most influential. Ayat-Ayat Cinta (The Verses of Love) is one of the Islamic novels that succeeded in gaining a million readers among the young Indonesian Muslim (Damayanti 2013; Rani 2012). Because of the success of this novel, it encouraged other young Muslim writers to produce literature that is called 'Islamic literature'. However, Islamic literature also became quite varied, with either supporting the Islamic worldview or criticizing the values.

There are some previous publications about the image of women in contemporary Indonesian literature. The first is "Indonesian Literature after 'Reformasi': The Tongues of Women" by Harry Aveling (2007). This paper deals with the emergence of female writers in the era of 'Reformasi'. According to Aveling, female writers bring their ideas, dream or idealism based on women's needs. This condition brings about good condition because the female writers will balance the discourse of the women's position in Indonesian literature (Aveling 2007). The second, publication is written by Diah Ariani Arimbi, "Reading contemporary Indonesian Muslim women writers: Representation, identity and religion of Muslim women in Indonesian fiction". This book is based on her Ph. D. thesis, which was published in 2009. This book raises the female authors who deal with the identity and religion on their novels (Arimbi 2009). Arimbi (2009) argues that it is a good chance for female authors to bring their ideology and ideas about women's position in Muslim society. The third is my publication entitled "Polygamy and Muslim Women in Contemporary Indonesian Literature". This paper was published in 2018, deals with the image of Mus- 
lim women in contemporary Indonesian literature. It specifically focuses on marriage and polygamy (Wajiran 2018).

Based on those previous publications, this paper is different. Most of the earlier publications focus more on the importance of the emergence of the female author in Indonesian literature. Meanwhile this paper raises the image of women based on male authors' perspective. This paper brings the perspective that sexual different will bring about different image of women. This is because the author's biological background brings different ideological views.

This paper applies sociology of literature which introduce the idea that literature cannot be separated from its society. Literature reflects the values of the society. At the same time, literature also influences the society. According to Abram, literature is like a mirror (Abrams 1953). A literary work reflects society. Based on this assumption, this paper will deal with how the author present the image of women, especially in the Indonesian context.

\section{Result}

Before discussing the interpretation of the literary works, it will be better to know about the authors. The historical background of the author is essential as their life experiences influence their works. The historical context presented in brief as they are very popular in Indonesia, especially for those who concern on Indonesian literature.

\section{Habiburrahman El Shirazy}

Habiburrahman El Shirazy can be called a pioneer in the literary authorship that promotes modern Islamic moral values in Indonesian literature. His literary works raise not only issues of Islamic morality, but also the values of humanity in general. One of his phenomenal literary works is Ayat-Ayat Cinta - the 
novel that became a film with the same title in 2004. According to Heryanto, the film gained 3.6 million viewers in forty days. This film is more popular than other famous works such as Harry Potter in Indonesia (Weintraub 2010; Heryanto 2012).

El Shirazy is a talented writer in many fields. He is a dai (Islamic preacher), film director, and leader in pesantren (Islamic Boarding school). Because of his ability in writing, he was awarded several awards. Take for example the award for the 'Man of Change' from the national newspaper, Republika in 2007, The Pen Award in 2005, for the novel Terpuji (Admirable) from Pen Circle Forum, the Most Favorite Book by Muslimah magazine in 2005, and the IBF Award in 2006 for producing the best book of national adult fiction (El Shirazy 2011, 280-83). Some of the awards given to him from higher education institutions include the Adab Award of Sunan Kalijaga University in 2008, the Archipelago Literary Award by the Language Centre of the Council Majelis Literature Southeast Asia (Mastera) 2008.

El Shirazy has written many novels, including: Ayat-Ayat Cinta (filmed in 2004), Di atas Sajadah Cinta (raised in screen by TransTV in 2004), Pudarnya Pesona Cleopatra (2005), Ketika Cinta Berbuah Surga (2005), Ketika Cinta Bertasbih (2005), Ketika Cinta Bertasbih 2 (2007), Dalam Mibrob Cinta (2007), Bumi Cinta (2010), and many others.

His works are famous due to their content supporting Islamic propagation. The moral values that are offered in his works become special values in the work of arts. This kind of work is very different from other (usually called secular) work that does not offer any "benefit" for the reader. As this work is a kind of an alternative media for Islamic propagation, it teaches the reader to be a good Muslim or at least to support the reader being better (Sakai 2012). This kind of literature matches the thirst of Indonesian people who have high spirituality. Religious prosely- 
tizing is very popular in the Indonesian context. Therefore, this literary work is a part of religious teaching.

The most interesting aspect that attracts Muslim readers is because his novels bring modern Islam. His idea of Islam is the moderate one. Therefore, it is acceptable in contemporary Indonesia. He does not use a traditional teaching model but modern Islamic ideology. This is reflected in the characters in his work, such as in Ayat-Ayat Cinta (2004), Ketika Cinta Bertasbih (2007) and Cinta Suci Zahrana (2011). The main characters of these three novels are depicted as very pious Muslims with functional social status, good educational backgrounds and good wellbeing. This model of characterization is very different with the previous era, such as in Tenggelamnya Kapan Vander Wijck (1938) by Hamka, Siti Nurbaya (1922) by Marah Rusli, and Layar Terkembang (1937) by Sutan Takdir Alisyahbana.

\section{Mustofa W. Hasyim}

Mustofa W. Hasyim is more senior than El Shirazy. He is from Kotagede, Yogyakarta. He was born on November $17^{\text {th }}$, 1954. He spends his life in Yogyakarta and gets his education in Islamic institutions. Since elementary school he studied in a $\mathrm{Mu}-$ hammadiah (second biggest Islamic organization in Indonesia) school institution. Besides studying Islamic studies, he also studies journalism in Balai Pendidikan Wartawan Jakarta (Journalist Education Center in Jakarta).

He improves his writing abilities by joining many cultural communities such as PSK (Persada Studi Klub, Universe Study Club), Kelompok Insani Harian masa Kini Yogyakarta (Yogyakarta Modern Human group), Sanggar Enam Dua Jakarta, kelompok Sembilan Jakarta and many others. He is also active in many cultural activities such as in Yayasan Budaya Masyarakat Indonesia (Yabumi), Yayasan Pondok Rakyat (YPR), Panitia Festival Kesenian Yogyakarta (FKY), and Dewan Kebu- 
dayaan Kota (DKK) Yogyakarta (Hasyim 2006, 177). His involvement in cultural activities shows that he has concern for culture and literature.

$\mathrm{He}$ is a reporter for one of the famous national newspapers in Indonesia. Besides that, he is also an active writer in newspapers, as well as being an editor. He has worked for several publications such as Harian Masa Kini, Harian Yogya Post, Kuntum, Rebana, Suara Muhammadiyah, Warta Kampung, Fadilah, and Jurnal Cerpen. Now he is still working for Suara Muhammadiyah, the magazine of Muhammadiyah, the second biggest Islamic organization in Indonesia. He is also a committee member of the Dewan Kebudayaan Kota Yogyakarta (Cultural Council of Yogyakarta) and a member of Lembaga Seni Budaya (Arts and Culture Institute) Muhammadiyah in Yogyakarta.

Sinse 2004 he wrote many novels dealing with women. Perempuan yang menolak Berdandan (Naration), Cinta Di Balik Kerudung, Sepanjang Garis Mimpi (Diva Press), Burung tak Bernama (LKIS), Endang, Cinta yang Tergenang and Perempuan Badai (2006) are regarded as works that deal with women's issues.

Images of Muslim Women in El Shirazy's novel, Cinta Suci Zahrana

The main character Zahrana is the representation of modern Indonesian women. She has a modern lifestyle and good life vision. It shows that she is a moderate Muslim that accord with contemporary society. Her relationships are not only limited to Muslims but also with various other communities. This can be seen in her participation in academic activities. Her position as a lecturer with many achievements indicates that she has good social relationships.

Zahrana is the representation of Javanese Muslim women in modern era. This is because, after the reformation era, the pos- 
sibility of women to participate in social and political activities is very open. Women are allowed to get higher education, join social, economic and political events. In new conditions, there are many women leaders such as in company, religious organizations and also governmental organizations; governor, minister, and regent and vice-regent (Dewi 2015). Those women public figures inspire the young generation to participate in public life and to raise women's existence in the public domain.

The emancipation of women primarily happens in big cities. Women are the majority member of schools and universities. This indicates that women already have the same rights as men in Indonesia now. Interestingly, after the reformation era, many Muslim female students prefer to wear the veil while attending university. This happens not only in Islamic universities but also in state universities. Universities do not push students to use the headcover, but many female students prefer to wear it.

Islam supports the empowerment for women in the corridor of Islamic moral values. This is because women in Islam also have the same position as men. However, some rules must be followed by both male and female in life. Both men and women have their responsibility based on their kodrat (nature) as men or women. Since the era of Prophet Muhammad, the insistence on freedom of speech and expression is constant in Muslim society. However, if religion does not provide rules on how to behave for human beings, all creatures will face destruction in the world. Similarly, freedom of sexual activities will be dangerous for social construction.

In accordance with women's empowerment, Lina (Zahrana's best friend) gives the example of great women in the era of the prophet and after the Prophet Muhammad. Some great women do extraordinary jobs as scientist, philosopher and businesswoman. Lina said "The essential frontier was the wives of 
Prophet Muhammad and his friends, his female friends. They studied diligently about Islamic knowledge and were given the same chance as men."

Lina is an example of a woman who has great knowledge, especially about hadith. This indicates that Islam does not restrict women from learning important things in their lives. Thus, we read of the great women of knowledge: "In fiqh (Islamic Jurisprudence) there was Amra binti Abdurrahman (98 H/716 M), and Hafsah binti Sirrin was an expert from Basrah.(El Shirazy 2011,166 ).

The great women in the era of the prophet and after the Prophet Muhammad become role models for Muslim women around the world. Therefore, there will be no discrimination and restriction for women to enrich their knowledge and skill as long as it is important for their life. Males and females alike have the same rights to participate in their society. However, if they get married, their activities must be coordinated with their spouse. Men and women have their specific potentiality in work; it will be complicated to work both caring for the household and to work outside at the same time. Therefore, both wife and husband need to discuss who will be responsible for the household and who will stay at home - although Islam clearly states that it is better for women to stay at home because there are greater responsibilities for women in the family (Farwah 2013; Wahib 2014).

Zahrana is the example of the ideal Muslim woman. Besides being depicted as a clever woman, she also cares about her existence in her social life. She obeys her family, friends, and neighbour as a vital component in her life. Her excellent education and her intellectuality do not make her stubborn about keeping her principle of living without marriage. Whereas, her obedience to her religion does not challenge her achievements. She still gets 
the award from Tshinghua University. The university awarded her because of her intellectuality in devising concepts in creative architecture (El Shirazy 2011,2). Not only that, some professors offer her a scholarship to continue her studies through a doctoral degree. One of whom is Professor Jiang Daohan. Others offer her to support her materializing her ideas in a project in Malaysia (El Shirazy 2011, 69-70).

Zahrana is the reflection of what we call a moderate Muslim. She has a broad-minded. She does not limit her friendships with other people. She is open to everyone. This fact is shown in her opinion about China that she can learn many things from China. This is important because Islam is very flexible regarding the civilization of human beings. Islam accommodates differences among the community because differentiation is one of God's powers and considered to be sunnatullah (natural) (El Shirazy 2011, 83).

Lina suggested that Zahrana marry first and then go to college. It would be safer for her because she has to pursue the perfection of her life as a Muslim. Even if she were married, she could still develop herself, continue her studies. Lina also states that she will continue her Master's degree. In her opinion, Islam gives the same chances for males and females to enrich their knowledge. Because of this rationale, Lina insists Zahrana accept the marriage proposal from Mr. Karman (El Shirazy 2011, $135)$.

The novel shows the changes in worldview about women. In the New Order and Old Order (pre-reformation in Indonesia) novels, the rule of parents was greater in determining their daughter's spouse, but this novel shows a very different picture. In Cinta Suci Zahrana, there is no coercion by parents in determining the spouse. Both the younger generation and their parents reveal their understanding of women's (daughters') inde- 
pendence in choosing their life partners. Parents can give advice, but the final decision is in the daughters.

The freedom of choosing a mate can be seen from the efforts of Zahrana in determining the choice of her life partner. Zahrana is independent in deciding whom she will marry. Besides Zahrana, the position of Lina is also vital in understanding the independence of Muslim women in choosing the spouse.

Lina is not only as an illustration of a devout Muslim woman, but she is also a representation of a Muslim who knows more about religion and the principles of life compared to Zahrana. That is why Lina is also very influential on the decisions taken by the main character, Zahrana (El Shirazy 2011, 174).

Meanwhile, the freedom given to Zahrana by her parents can be seen from the statement of Mr. Munajat when responding to Mr. Karman's proposal. Pak Munajat wisely said that both Zahrana's parents give freedom to Zahrana. Zahrana herself knows about her future (El Shirazy 2011, 194).

\section{Images of women in Hasyim's novel, Perempuan Badai}

The main concern of this novel is about a career woman in a family. A woman who is busy with her jobs will face the difficulties in handling the household. This situation will become a problem in the Javanese family because a woman usually responsible for the house. Even though this is not a fixed rule, Javanese culture has an unwritten agreement that a wife should stay at home and be responsible for caring for her family. This moral value is greatly influenced by Islamic moral values that man is the leader in a family.

Nurjanah, as the main character in this novel, is depicted as a professional woman. As a lecturer, she is very independent. She is a woman with good intellectuality. She is very broadminded. However, her intellectuality does not enlighten her position as a wife in her family. It becomes a burden and disturbs her marriage. 
This novel deals with the influence of translated book to the main character, Nurjanah. The influence of thought from other countries is not always good for the Javanese family. As a consequence, Nurjanah is brave in opposing her husband. In Javanese culture, it is a deep-seated taboo to disobey husband. Javanese culture teaches that as a woman (wife) has to obey whatever her husband instructed. Islam urges that man is the leader in the family. Therefore, there is no reason to disobey the husband except the husband destroys Islamic moral values.

The problem that is often faced by a career woman is that she finds it challenging to be pregnant. This happens to Nurjanah, even she has married almost ten years, but she still does not get any child (Hasyim 2006, 135). This is the challenge and the most significant problem in her marriage.

Ironically, Nurjanah is more concerned with her friend Narsih. Narsih is a woman activist who promotes freedom of speech and expression for women. Narsih is more influential to Nurjanah than her husband. Narsih is from a disparate, broken, and unhappy family. The family problem influences much on her way of life. Her disappointment to her father makes her to spoil the normative values.

The issue of a career woman indicated as a problem in the Muslim family is due to Islam giving a clear guide in family formation. A division of labour enables both wife and husband to handle jobs based on their respective responsibilities. Even though it is not always the wife who has to be responsible for the household. Both wife and husband can discuss their duties based on their talents and capabilities. However, in traditional Javanese Muslim, women should be advised to be responsible for the household, rather than working outside.

Islam gives guidance to job divisions in the family because human beings have very limited power for handling all of the 
works involved. If both wife and husband are busy with their businesses, they will forget to take care of their children. As a result, this will endanger their children sociologically and emotionally. Children are the most important assets in Javanese society as well as in Islamic culture. Therefore, Islam urges each Muslim to work based on their potentiality and does not want hardship for human beings.

The impact of feminism followed by Nurjanah greatly influences her way of life. As a result, she has to accept the consequence of her attitude - a broken family. Her attitude, regarded as "immoral", makes her husband decides to have an affair with another woman. This is the situation that commonly resulted from the wife's disobedience. The husband will run to other women if the wife does not obey him (Hasyim 2006, 111).

Besides the disobedience of his wife, Anwar is upset because he realizes that Nurjanah cannot give birth. In this case, Anwar blames this failure on his wife being infertile. He also believes that his marriage is unblessed. Not only Anwar who blame Nurjanah's infertility, it is also the society perception to blame the wife as the troublemaker (Hasyim 2006, 45).

The failure to have children is associated with Nurjanah's busyness. Her position as a career woman is blamed as the troublemaker. Nurjanah also recognizes that she miscarried her baby because she was so stressed in facing a final exam. She was too busy that she was unable to remain healthy (Hasyim 2006, 60). Nurjanah feels exceptionally guilty because of this accident and admits that it is her mistake because of her being busy with her own business.

Nurjanah's disappointment with her condition makes her feel frustrated. Her own family terrorizes her and people question her about children. As a result, she thinks that being married is a big problem for her. She feels that she cannot be indepen- 
dent. She feels that her family has become a significant obstacle to her independence and personal freedom (Hasyim 2006, 90).

As the reflection of her disappointment, Nurjanah rebels against the social and religious norms. As a sign of her rebellion, she does not wear a veil to go to her office. She says that she wants to be an independent and to be herself. She realizes that this decision is not only disappointing her husband but also to those around her. Her colleagues and friends in her university interrogate her. As this attitude is unusual, this attitude raises many assumptions that she must face family problems (Hasyim 2006, 122).

Nurjanah takes this decision caused by her understanding of feminism. The feminist idea influences Nurjanah's assumptions about personal independence greatly. She believes that as a woman, she has to use her own body and thoughts, without considering others' perceptions. She does not want to be interrupted by social perceptions, as she would be in a challenging situation in responding to many negative opinions, because of her inability to give birth. She says that freedom as a human being, as an autonomous woman, and as somebody having a body is hers. Therefore, she decides whether to wear the veil over her body. Nobody can insist that she cover her hair because her hair needs fresh air (Hasyim 2006, 122).

This happens because clothes are crucial in Islam. Dress is a part of identity. Clothing is also a sign of human dignity. Therefore, if one has a daughter with a very open dress, it will disrupt her dignity and her family will be ashamed of this. Since the incident, Nurjanah becomes very angry with her father and does not want to meet him. She always keeps away from her father. She is not only angry with her father personally but also hates her father because of his bad attitude toward women (Hasyim 2006, 127). 
Nurjanah's rebellion to her stressful condition is not the solution for her life, because it will only make her more disappointed. Her husband does not change his mind to be more love with her. Yet her husband runs from her by having a secret relationship with her servant. This situation makes her extraordinarily depressed and upset with her husband. She does not know why Anwar can do this with a woman who is far lower in social status than her. She was unaware that her husband would do it (Hasyim 2006, 151).

As a consequence, Nurjanah rebels against social and moral values. She does not want to listen to other people. She rejects all social norms that she regards as obstacles for her success. She does not want to be restricted by social perception (Hasyim 2006, 89).

\section{Discussion}

Based on the result of this research, both writers present different perspectives on Muslim women. However, both authors support the traditional Islamic moral values on their literature. This can be assumed that El Shirazy and Hasyim champion the traditional Islamic values in their novels. These novels are very normative, although they are in a different viewpoint.

Both authors present the importance of the implementation of Islamic moral values in the society. However, El Shirazy presents the main character who is more submissive to the social norm as well as patriarchal ideology. Meanwhile, Hasyim presents a female character who tries to go away from the domination of patriarchy.

As reflected in these novels, one of the essential characteristics of a good woman is the attitude (akblaq). Akblaq is an Arabic term referring to the practice of virtue, morality and manners in Islamic theology and philosophy. In other words, akblaq is the temper, ethics, or behaviors of a person. Akblaq is one of 
the most significant aspects of Islamic teaching. Therefore, the final goal of Islamic education is the change in attitude (Akblaq). This means that when someone believes in Islam, his/her attitude must be better than those who do not know Islam (Gadeng, 2009). Finally, one who believes in Islam and has the right attitude is called sholeh, or sholehah for a woman (Rinaldo 2011).

The authors depict female characters differently because of their social and political background. In Cinta Suci Zabrana, Zahrana is described as a pious Muslim woman who obeys her parents as well as her society. This can be seen on how she consistently, wearing a veil when she is working. The Muslim dress is embedded in her personality and became her lifestyle. On the other hand, the depiction of Zahrana is different from the depiction of woman in Hasyim's novel. Even though Nurjanah is described as having a religious family background, she does not consistently wear jilbab. This can be seen when she is angry with Anwar. She goes to her office without wearing headscarf.

El Shirazy presents more religious female characters than Hasyim. This can be seen when Zahrana faces difficulty in getting a spouse. She keeps the values in her life. On the other hand, Nurjanah does not want to keep the moral values when she avoids her husband's instructions. In many scenes, Zahrana is depicted very open person with many friends. This indicates that Zahrana follows moderate Islam. She believes that Islam allows the relationship between men and women as long as it does not spoil the moral values. This depiction is very different with Nurjanah. She has very limited friends.

El Shirazy supports patriarchal values as can be seen from the depiction that Zahrana's piousness is based on the male perspective, not from her interpretation of Islam. Zahrana always wants to follow her parent's will (especially her father's interest). She is also depicted always having a psychological burden to 
choose her own life (for example, as a career woman), because of her unmarried even when she is more than thirty years old. Whereas, Hasyim depicts female characters more progressive. Nevertheless, he puts the female figure as a looser party at the end of his story.

\section{Conclusion}

These two novels show that there is a development in presenting the image of Muslim women. There is a development of thoughts, especially about the social status of women. The changes include the level of education, determination of spouse, and freedom to participate in public spheres. The level of education obtained by the main characters is an essential milestone in changing women's position in Indonesian Muslim society. Women are not just an object, but they should be the subject in the life of the Muslim community.

Even though these novels change in describing the female characters, both of these novels still adopt the ideology of patriarchy. El Shirazy and Hasyim depict that women who choose to have public sphere responsibility will face life difficulties, especially that deal with their right in family. This can be seen in the characters of Zahrana and Nurjanah, who are not happy with their marriage because of their choice to be more independent.

Based on these two novels, it can be concluded that to have a happy family, women should obey the values of their religion and society. Women are the member of community. Therefore, they should follow what is good or bad based in the society. Women have limited ability and weakness. Therefore, the idea to be more independence is not the guarantee to be happy.

\section{Bibliography}

Abrams, Meyer Howard. 1953. The Mirror and the Lamp: Romantic Theory and the Critical Tradition. Vol. 360. New York: Oxford University Press. 
Arimbi, Diah Ariani. 2009. Reading Contemporary Indonesian Muslim Women Writers: Representation, Identity and Religion of Muslim Women in Indonesian Fiction. Vol. 3. Amsterdam: Amsterdam University Press.

Aveling, Harry. 2007. "Indonesian Literature after"Reformasi”: The Tongues of Women." Kritika Kultura 8: 9-53.

Damayanti, Eka. 2013. “Analisis Nilai Moral Novel Cinta Suci Zahrana Karya Habiburrahman El Shirazy Dan Skenario Pembelajarannya Di Kelas XI SMA.” SURYA BAHTERA 1 (07).

Danerek, Stefan. 2006. Tjerita and Novel. Literary Discourse in Post New Order Indonesia. Lund University.

Dewi, Kurniawati Hastuti. 2015. Indonesian Women and Local Politics: Islam, Gender and Networks in Post-Suharto Indonesia. Singapore: NUS Press.

El Shirazy, Habiburrahman. 2011. Cinta Suci Zabrana. Ar-Risalah Product.

Farwah, Aliyah. 2013. "Faktor Sosial Terhadap Kesejahteraan Islami Keluarga Muslim Di Kota Surabaya." Jurnal Ekonomi Dan Bisnis Airlangga (JEBA)l Journal of Economics and Business Airlangga 23 (2).

Hasyim, Mustofa W. 2006. Perempuan Badai. Yogyakarta: Panda.

Heryanto, Ariel. 2012. Budaya Populer di Indonesia: Mencairnya Identitas Pasca-Orde Baru. Yogyakarta: Jalasutra. https:// openlibrary.telkomuniversity.ac.id/pustaka/143198/budaya-populer-di-indonesia-mencairnya-identitas-pasca-orde-baru.html.

Nasrullah, Nurdin. 2013. Sastra Adab Nusantara Dalam Bingkai Sejarah. Jakarta: Universitas Islam Negeri Syarif Hidayatullah. 
Osman, Rahmah Ahmad. 2008. "Defining Islamic Literature." International Journal of the Humanities 5 (11).

Rani, Mohd Zariat Abdul. 2012. "Islam, Romance and Popular Taste in Indonesia: A Textual Analysis of Ayat Ayat Cinta by Habiburrahman El-Shirazy and Syahadat Cinta by Taufiqurrahman Al-Azizy." Indonesia and the Malay World 40 (116): 59-73.

Rinaldo, Rachel. 2011. "Muslim Women, Moral Visions: Globalization and Gender Controversies in Indonesia." Qualitative Sociology 34 (4): 539-60.

Rosidi, Ajip. 1995. Sastera dan Budaya: Kedaerahan Dalam Keindonesiaan. Dunia Pustaka Jaya.

Sakai, Minako. 2012. "Preaching to Muslim Youth in Indonesia: The 'dakwah' Activities of Habiburrahman El Shirazy." RIMA: Review of Indonesian and Malaysian Affairs 46 (1): 9.

Wahib, Ahmad Bunyan. 2014. “'Reformasi’ Hukum Keluarga Di Dunia Muslim." Ijtihad: Jurnal Wacana Hukum Islam Dan Kemanusiaan 14 (1): 1-19.

Wajiran, Wajiran. 2018. "Polygamy and Muslim Women in Contemporary Indonesian Literature." Jurnal Humaniora 30 (3): 291-304.

Weintraub, Andrew N. 2010. Dangdut Stories: A Social and Musical History of Indonesia's Most Popular Music. Oxford University Press. 